CLINICAL STUDY

\title{
GH secretagogue receptor gene polymorphisms are associated with stature throughout childhood
}

\author{
Stefan Riedl $^{1,2, *}$, Ian Hughes ${ }^{3, *}$, Mark Harris ${ }^{4}$, Gary M Leong ${ }^{4,5}$, John Beilby ${ }^{6,7}$, Peter Sly ${ }^{8}$ and Catherine S Choong ${ }^{2,9}$ \\ ${ }^{1}$ Pediatric Department, St Anna Children's Hospital, Medical University of Vienna, 1090 Vienna, Austria, ${ }^{2}$ Department of Endocrinology and Diabetes, \\ Princess Margaret Hospital for Children, Subiaco, Western Australia, Australia, ${ }^{3}$ The Children's Nutrition Research Centre, Discipline of Paediatrics and \\ Child Health, University of Queensland, Herston, Queensland, Australia, ${ }^{4}$ Department of Endocrinology and Diabetes, Mater Children's Hospital, \\ South Brisbane, Queensland, Australia, ${ }^{5}$ Institute for Molecular Bioscience, Obesity Research Centre, University of Queensland, St Lucia, Queensland, \\ Australia, ${ }^{6}$ School of Pathology and Laboratory Medicine, University of Western Australia, Crawley, Western Australia, Australia, ${ }^{7}$ Molecular Genetics, \\ PathWest Laboratory Medicine, Nedlands, Western Australia, Australia, ${ }^{8}$ Queensland Children's Medical Research Institute, Royal Children's Hospital, \\ Herston, Queensland, Australia and ${ }^{9}$ School of Paediatrics and Child Health, University of Western Australia, Perth, Western Australia, Australia \\ (Correspondence should be addressed to S Riedl at Pediatric Department, St Anna Children's Hospital, Medical University of Vienna; Email: \\ stefan.riedl@meduniwien.ac.at)
}

*(S Riedl and I Hughes contributed equally to this work)

\begin{abstract}
Context: Ghrelin plays a major role in GH physiology and energy metabolism. Polymorphisms of its receptor (GH secretagogue receptor (GHSR)) may influence childhood growth and weight regulation. Objective: To correlate GHSR polymorphisms with auxological parameters throughout childhood in a healthy cohort.

Study design: Longitudinal retrospective population-based genetic association study.

Subjects and methods: GHSR genotypes were evaluated in 1362 children and compared with height/length, weight, and body mass index (BMI) data across an observation span of 10 years $(0,1,3$, 5, 8, and 10 years). Five different GHSR SNPs (rs2922126, rs2981464, rs482204, rs562416, and rs572169), minor allele frequency $>0.1$, were genotyped. Identification of potential genetic associations with height, weight, and BMI, using additive and dominant/recessive models, was optimized by comparing allele or genotype frequencies between the tallest and the shortest $27 \%$ of subjects for each auxological variable. Significance of association was evaluated by $\chi^{2}$ test.

Results: The rs482204 TT genotype, vs TC/CC, was associated with greater stature across the entire observation period $(P<0.05)$. Similarly, the rs562416 TT genotype, vs TG/GG, correlated positively with tall stature at 3, 8, and 10 years. Other SNPs and genotypes showed no association with height at any age. No association was found between any tested SNPs and weight or BMI.

Conclusions: Longitudinal investigation between birth and 10 years in a population-based cohort revealed a significant association of the rs482204 and rs562416 GHSR polymorphisms on height, whereas no association between GHSR polymorphisms and weight or BMI was ascertainable.
\end{abstract}

European Journal of Endocrinology 166 1079-1085

\section{Introduction}

Diversity of adult human height within a population is largely explained $(>80 \%)$ by genetic variation and hence represents an ideal model for studies elucidating common complex traits with a moderate to high heritability. The GH/insulin-like growth factor (IGF) axis represents the most important pathway determining growth, with additive effects on many different novel genes continuing to be discovered (1). Ghrelin, the endogenous ligand for the $\mathrm{GH}$ secretagogue receptor (GHSR), stimulates GH release in addition to causing weight gain through increased food intake and reduced fat utilization $(2,3)$. Common ghrelin gene variants have been investigated for a potential influence on stature (4) and body weight $(5,6)$ without significant associations being detected.

GHSR, located on chromosome 3q26.3 (MIM* 601898), encodes a G-protein-coupled receptor that was discovered in 1996 before its natural ligand, ghrelin (7). It gives rise to two splice variant mRNAs encoding GHSR $1 a$ and GHSR 1b. GHSR 1a consists of 366 amino acids, with seven transmembrane domains. GHSR $1 b$ consists of 289 amino acids with five transmembrane domains. GHSR 1a has a high affinity and specificity for binding of GH secretagogues (GHS), whereas GHSR $1 b$ does not bind GHS.

Importantly, GHSR shows high constitutive activation, and even in the absence of ghrelin, the receptor signals at $50 \%$ of its maximal capacity in vitro (8). 
In contrast to many other systems regulated by two ligands acting as agonists on two distinct receptors with opposite signaling effects, ghrelin seems to serve as a unique agonist that fine-tunes the action of GHSR with no endogenous inverse agonist yet discovered. Its peculiar nature makes GHSR an interesting candidate gene to look for the effects of genetic alterations of GHSR on stature and body weight.

Indeed, Pantel et al. (9) described a loss of constitutive activity of the GHSR caused by a dominant disruptive mutation (Ala204Glu), which was associated with idiopathic short stature in one family and with isolated GH deficiency in another. Later, this group also reported a patient with isolated $\mathrm{GH}$ deficiency due to compound heterozygous GHSR mutations (10). Similarly, a significantly higher occurrence of four novel heterozygous GHSR variants was observed in 127 Japanese patients with either GH deficiency or short stature compared with controls (4.72 vs $0.53 \%$ ) (11).

Several large studies in various populations have investigated the effects of common GHSR variants on stature, weight, and body mass index (BMI) $(4,5,12$, 13, 14, 15). Baessler et al. (12) reported an association between GHSR variants and obesity; however, other studies have yielded negative results $(5,13,14,15)$.

Here, we present an investigation of possible associations between common GHSR variants and statural growth, weight, and BMI. In contrast to the crosssectional design of most previous studies, we had the unique opportunity to perform a population-based longitudinal study, which followed 1362 healthy children from birth to 10 years of age.

\section{Subjects and methods}

\section{Subjects}

The Western Australian Pregnancy Cohort (Raine) Study (www.rainestudy.org.au) was designed to measure the relationships between early life events and subsequent health and behavior. This is one of the largest and most closely followed prospective cohorts in the world. Recruitment has previously been described in detail (16). In brief, 2900 pregnant women were enrolled between 1989 and 1991 through the state maternity hospital, King Edward Memorial Hospital (KEMH), and nearby private clinics in Perth, Western Australia, into a randomized controlled trial to evaluate the effects of repeated ultrasound exposure in pregnancy. These women were recruited between 16 and 20 weeks of gestation (mean 18 weeks), with sufficient English language skills and an intention to deliver their baby at KEMH and to reside in Western Australia. They delivered 2868 live-born children. Mothers provided data regarding pregnancy, maternal physical health, and psychosocial and demographic characteristics at enrollment and at 34 weeks of gestation.
The analyses in this study were based on $1362(660$ females and 702 males) Raine Study children who met the criteria of live, unrelated, singleton births, with no congenital abnormalities who attended for regular follow-up. No other exclusion criteria such as preterm birth, low birth weight, or chronic illness were applied. These children were genotyped for the five SNPs across the GHSR gene described. Anthropometric data at birth and 1 , $3,5,8$, and 10 years were available. Among the 586 girls evaluated for 10 years, menarche data could be obtained in $546(93.2 \%)$, and $14(2.6 \%)$ had already experienced menarche at the time of their measurements. The protocols for the study were approved by the Human Research Ethics Committees at KEMH and/or Princess Margaret Hospital for Children in Perth, Western Australia.

\section{Sequencing and SNP selection}

Sequencing of GHSR SNPs A salting out method was used to isolate genomic DNA from leukocytes. Sequencing of the promoter region, exons 1 and 2 in GHSR, plus the $3^{\prime}$-UTR was performed using Ensembl Transcript ENST00000241256 as reference sequence. SNPs were genotyped using TaqMan (ABI Prism 7900HT Sequence Detection System; Applied Biosystems, Foster City, CA, USA) except for rs2981464, which was genotyped using Amplification Refractory Mutation System-PCR (17). For confirmation of results, samples of each genotype were sequenced and subsequently used as controls in each experiment. To ensure that the data were reproducible, $10 \%$ of the samples were genotyped in duplicate. Details on genotyping (primers, probes, and PCR conditions) are available on request.

To discover common genetic variants in our population group, we selected five SNPs (rs2922126, rs2981464, rs482204, rs562416, and rs572169) based on linkage disequilibrium (LD; $\Delta^{2}<0.8$ ) and minor allele frequency $>0.1$ (range $0.11-0.46$ ) covering the whole gene including the $5^{\prime}$-UTR promoter and 3'-UTR (http://manticore.niehs.nih.gov).

\section{Analyses and statistics}

Lengths/heights, weights, and BMIs of individuals within each year cohort were converted to SDS. As these cohorts were random population samples, height SDSs were calculated with respect to the sample population. All heights, weights, and BMIs were first, for girls and boys separately, normalized for age within the age group by regressing the actual value to an estimated value at the beginning of the age group, e.g. to 2 years of age for the 2- to 3 -year olds. The mean and s.D. of these values were then used to calculate the SDS $(\mathrm{SDS}=($ regressed value - mean $) /$ s.D. $)$. Birth data were normalized with respect to length of gestation to 40 weeks. Actual weights and lengths were used for babies 
born after 40 weeks, as mean values for these babies were not significantly different to those born at 40 weeks.

Association analysis of SNP alleles with height, weight, and BMI was based on a comparison of the top and bottom $27 \%$ of the population according to trait SDS. This percentage has been shown to be the theoretical optimum proportion of a distribution to detect allelic association with variation in a quantitative trait $(18,19)$.

Additive and dominant/recessive models for each allele were tested. For the additive model, allele frequency differences were compared between groups by a $\chi^{2}$ test. For each dominant/recessive model, the putative recessive-homozygote genotype frequency and the combined heterozygote and dominant homozygote frequencies were compared between groups by $\chi^{2}$ test. Hardy-Weinberg equilibrium was tested using a $\chi^{2}$ test by comparing observed genotype frequencies with those predicted.

\section{Results}

\section{Anthropometric data}

Mean (s.D.) height, weight, and BMI values regressed to the starting age of each cohort as well as percentages of overweight/obese subjects are presented in Table 1.

\section{Sequencing of SNPs}

There was a 0\% error rate detected for all SNPs analyzed. All SNPs for each year were in HardyWeinberg equilibrium except for rs562416 at year 1 $(P=0.046)$.

\section{Association of GHSR SNPs with length/height in the tallest $27 \%$ and shortest $27 \%$}

Additive model and dominant/recessive model Applying the additive model, the T allele of rs482204 was significantly more common in the tallest $27 \%$ at birth, 1, 3, and 5 years compared with the shortest
$27 \%$. Using the dominant/recessive model, the TT genotype significantly predominated in the tall cohort at all time points. The rs562416 TT genotype was observed significantly more frequently in the tallest $27 \%$ at 3, 8, and 10 years (Table 2). Both SNPs (rs482204 and rs562416) were located within the 3'-UTR region. Nonassociations were observed for SNPs rs2922126, rs2981464, and rs572169.

\section{Association of rs482204 and rs562416 with length/height in the whole population}

SNPs that had shown significant associations with height/length in the tallest/shortest 27\% (rs482204 and rs562416) were subsequently tested in the whole study population. In accordance, the TT genotype of rs482204 was positively associated with height/length compared with TC/CC $(P<0.05)$ across the observation span in the whole study population, except for year 1 . No difference between genders was ascertainable (Fig. 1). The TT genotype of rs562416 also correlated positively with height at $3,5,8$, and 10 years in the whole population. Interestingly, we observed a significant gender difference in height within the rs562416GG individuals in years $1(P=0.02), 5(P=0.03), 8$ $(P=0.01)$, and $10(P=0.03)$ with males taller and females shorter (Fig. 1). However, the number of individuals with this genotype (4-6 females and 6-10 males) was very small ( $\approx 1.2 \%$ ). It should also be noted that although the GG individuals, as a group, appear to be taller than the TG and TT genotype individuals, this difference was not significant at any age.

\section{Association of GHSR SNPs with weight and BMI}

Additive model and dominant/recessive model No associations between five tested SNPs and weight or BMI were observed, either in the additive or in the dominant/recessive model.

Table 1 Anthropometric data of age cohorts.

\begin{tabular}{|c|c|c|c|c|c|c|}
\hline & Birth & Year 1 & Year 3 & Year 5 & Year 8 & Year 10 \\
\hline \multicolumn{7}{|c|}{ Height $(\mathrm{cm})$ mean (S.D.) ${ }^{a}$} \\
\hline Male & $50.3(2.1)$ & $76.3(2.9)$ & $96.6(3.8)$ & $112.1(5.0)$ & $129.0(5.9)$ & $141.8(6.8)$ \\
\hline Female & $49.6(2.3)$ & $74.8(2.5)$ & $95.0(3.4)$ & $110.9(4.5)$ & $128.1(5.4)$ & $141.6(6.6)$ \\
\hline \multicolumn{7}{|c|}{ Weight $(\mathrm{kg})$ mean (S.D.) ${ }^{\mathrm{a}}$} \\
\hline Male & $3.66(0.4)$ & $10.2(1.2)$ & $15.2(1.8)$ & $19.8(3.4)$ & $28.3(5.8)$ & $37.9(9.1)$ \\
\hline Female & $3.57(0.5)$ & $9.5(1.1)$ & $14.6(1.8)$ & $20.3(3.3)$ & $27.7(5.6)$ & $39.0(8.8)$ \\
\hline \multicolumn{7}{|c|}{ BMI $\left(\mathrm{kg} / \mathrm{m}^{2}\right)$ mean (s.D. $)^{a}$} \\
\hline Male & - & $17.5(1.4)$ & $16.2(1.2)$ & $15.7(1.7)$ & $16.9(2.5)$ & $18.6(3.4)$ \\
\hline Female & - & $16.6(1.3)$ & $16.1(1.3)$ & $16.4(1.8)$ & $16.8(2.6)$ & $18.8(3.3)$ \\
\hline \multicolumn{7}{|c|}{ Overweight ((obese) \%) } \\
\hline Male & - & - & $11.9(6.2)$ & $10.5(7.2)$ & $11.9(9.7)$ & $15.1(11.9)$ \\
\hline Female & - & - & $13.9(4.8)$ & $13.1(5.4)$ & $14.0(6.7)$ & $16.0(7.8)$ \\
\hline
\end{tabular}

${ }^{\mathrm{a}}$ Mean (S.D.) values regressed to starting age of cohort.

b Based on the BMI-SDS (CDC-2000) at actual age. Overweight: >85th centile but $\leq 95$ th centile for BMI-SDS. Obese: >95th centile for BMI-SDS. 
Table 2 Relative frequencies of GH secretagogue receptor (GHSR) SNP alleles and genotypes found to be associated with height.

\begin{tabular}{|c|c|c|c|c|c|c|c|c|c|c|c|c|}
\hline SNP/model & \multicolumn{2}{|c|}{ Birth } & \multicolumn{2}{|c|}{ Year 1} & \multicolumn{2}{|c|}{ Year 3} & \multicolumn{2}{|c|}{ Year 5} & \multicolumn{2}{|c|}{ Year 8} & \multicolumn{2}{|c|}{ Year 10} \\
\hline rs482204 & \multicolumn{2}{|c|}{$n=1330$} & \multicolumn{2}{|c|}{$n=1240$} & \multicolumn{2}{|c|}{$n=927$} & \multicolumn{2}{|c|}{$n=1217$} & \multicolumn{2}{|c|}{$n=1217$} & \multicolumn{2}{|c|}{$n=1198$} \\
\hline Additive & & & & & & & & & & & & \\
\hline Allele & $\mathrm{T}$ & C & $\mathrm{T}$ & C & $\mathrm{T}$ & C & $\mathrm{T}$ & C & $\mathrm{T}$ & C & $\mathrm{T}$ & C \\
\hline Population & 0.74 & 0.26 & 0.74 & 0.26 & 0.74 & 0.26 & 0.74 & 0.26 & 0.74 & 0.26 & 0.74 & 0.26 \\
\hline Shortest $27 \%$ & 0.71 & 0.29 & 0.72 & 0.28 & 0.70 & 0.30 & 0.71 & 0.29 & 0.72 & 0.28 & 0.71 & 0.29 \\
\hline Tallest $27 \%$ & 0.77 & 0.23 & 0.77 & 0.23 & 0.80 & 0.20 & 0.77 & 0.23 & 0.75 & 0.25 & 0.76 & 0.24 \\
\hline$P$ value & \multicolumn{2}{|c|}{0.020} & \multicolumn{2}{|c|}{0.033} & \multirow{2}{*}{\multicolumn{2}{|c|}{0.001}} & \multirow{2}{*}{\multicolumn{2}{|c|}{0.014}} & \multirow{2}{*}{\multicolumn{2}{|c|}{0.119}} & \multirow{2}{*}{\multicolumn{2}{|c|}{0.068}} \\
\hline C-dominant & & & & & & & & & & & & \\
\hline Genotype & $\mathrm{TT}$ & $\mathrm{TC} / \mathrm{CC}$ & TT & $\mathrm{TC} / \mathrm{CC}$ & $\mathrm{TT}$ & $\mathrm{TC} / \mathrm{CC}$ & TT & $\mathrm{TC} / \mathrm{CC}$ & TT & $\mathrm{TC} / \mathrm{CC}$ & TT & $\mathrm{TC} / \mathrm{CC}$ \\
\hline Population & 0.55 & 0.45 & 0.54 & 0.46 & 0.54 & 0.46 & 0.54 & 0.46 & 0.55 & 0.45 & 0.54 & 0.46 \\
\hline Shortest $27 \%$ & 0.50 & 0.50 & 0.51 & 0.49 & 0.50 & 0.50 & 0.49 & 0.51 & 0.49 & 0.51 & 0.49 & 0.51 \\
\hline Tallest $27 \%$ & 0.59 & 0.41 & 0.60 & 0.40 & 0.62 & 0.38 & 0.59 & 0.41 & 0.57 & 0.43 & 0.58 & 0.42 \\
\hline$P$ value & \multicolumn{2}{|c|}{0.020} & \multirow{2}{*}{\multicolumn{2}{|c|}{0.020}} & \multirow{2}{*}{\multicolumn{2}{|c|}{0.005}} & \multirow{2}{*}{\multicolumn{2}{|c|}{0.010}} & \multirow{2}{*}{\multicolumn{2}{|c|}{0.042}} & & \\
\hline T-dominant & & & & & & & & & & & & \\
\hline Genotype & $\mathrm{TT} / \mathrm{TC}$ & $\mathrm{CC}$ & $\mathrm{TT} / \mathrm{TC}$ & $\mathrm{CC}$ & $\mathrm{TT} / \mathrm{TC}$ & $\mathrm{CC}$ & $\mathrm{TT} / \mathrm{TC}$ & $\mathrm{CC}$ & $\mathrm{TT} / \mathrm{TC}$ & $\mathrm{CC}$ & $\mathrm{TT} / \mathrm{TC}$ & $\mathrm{CC}$ \\
\hline Population & 0.94 & 0.06 & 0.94 & 0.06 & 0.93 & 0.07 & 0.94 & 0.06 & 0.94 & 0.06 & 0.94 & 0.06 \\
\hline Shortest $27 \%$ & 0.92 & 0.08 & 0.93 & 0.07 & 0.91 & 0.09 & 0.93 & 0.07 & 0.94 & 0.06 & 0.93 & 0.07 \\
\hline Tallest $27 \%$ & 0.95 & 0.05 & 0.94 & 0.06 & 0.97 & 0.03 & 0.95 & 0.05 & 0.94 & 0.06 & 0.93 & 0.07 \\
\hline$P$ value & & 223 & & 533 & & 05 & & & & & & \\
\hline rs562416 & $n=$ & 1338 & & 1247 & & 922 & & 1223 & & 22 & & 04 \\
\hline Additive & & & & & & & & & & & & \\
\hline Allele & $\mathrm{T}$ & $\mathrm{G}$ & $\mathrm{T}$ & $\mathrm{G}$ & $\mathrm{T}$ & $\mathrm{G}$ & $\mathrm{T}$ & G & $\mathrm{T}$ & G & 1 & G \\
\hline Population & 0.86 & 0.14 & 0.86 & 0.14 & 0.86 & 0.14 & 0.86 & 0.14 & 0.86 & 0.14 & 0.86 & 0.14 \\
\hline Shortest $27 \%$ & 0.86 & 0.14 & 0.85 & 0.15 & 0.84 & 0.16 & 0.85 & 0.15 & 0.84 & 0.16 & 0.85 & 0.15 \\
\hline Tallest $27 \%$ & 0.85 & 0.15 & 0.87 & 0.13 & 0.87 & 0.13 & 0.87 & 0.13 & 0.88 & 0.12 & 0.88 & 0.12 \\
\hline$P$ value & & 706 & & 134 & & 88 & & 80 & & 59 & & \\
\hline G-dominant & & & & & & & & & & & & \\
\hline Genotype & TT & $\mathrm{TG} / \mathrm{GG}$ & TT & $\mathrm{TG} / \mathrm{GG}$ & TT & $\mathrm{TG} / \mathrm{GG}$ & TT & $\mathrm{TG} / \mathrm{GG}$ & TT & $\mathrm{TG} / \mathrm{GG}$ & TT & $\mathrm{TG} / \mathrm{GG}$ \\
\hline Population & 0.74 & 0.26 & 0.73 & 0.27 & 0.73 & 0.27 & 0.74 & 0.26 & 0.73 & 0.27 & 0.74 & 0.26 \\
\hline Shortest $27 \%$ & 0.73 & 0.27 & 0.71 & 0.29 & 0.68 & 0.32 & 0.70 & 0.30 & 0.68 & 0.32 & 0.70 & 0.30 \\
\hline Tallest 27\% & 0.73 & 0.27 & 0.75 & 0.25 & 0.76 & 0.24 & 0.76 & 0.24 & 0.77 & 0.23 & 0.78 & 0.22 \\
\hline$P$ value & & 933 & & 23 & & 08 & & 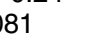 & & & & \\
\hline T-dominant & & & & & & & & & & & & \\
\hline Genotype & $\mathrm{TT} / \mathrm{TG}$ & GG & $\mathrm{TT} / \mathrm{TG}$ & GG & $\mathrm{TT} / \mathrm{TG}$ & GG & $\mathrm{TT} / \mathrm{TG}$ & GG & $\mathrm{TT} / \mathrm{TG}$ & GG & $\mathrm{TT} / \mathrm{TG}$ & GG \\
\hline Population & 0.99 & 0.01 & 0.99 & 0.01 & 0.99 & 0.01 & 0.99 & 0.01 & 0.99 & 0.01 & 0.99 & 0.01 \\
\hline Shortest $27 \%$ & 0.99 & 0.01 & 0.99 & 0.01 & 1.00 & 0.00 & 0.99 & 0.01 & 0.99 & 0.01 & 0.99 & 0.01 \\
\hline Tallest 27\% & 0.98 & 0.02 & 0.98 & 0.02 & 0.98 & 0.02 & 0.98 & 0.02 & 0.98 & 0.02 & 0.99 & 0.01 \\
\hline$P$ value & & 203 & & 203 & & 178 & & 54 & & 54 & & \\
\hline
\end{tabular}

Figures in bold represent $P<0.05$.

\section{Discussion}

We performed a longitudinal genetic association study of five different GHSR SNPs in a population of healthy children at six different time points from birth until 10 years of age. A significant association between rs482204 and stature was observed across the entire time span, including at birth. Similarly, rs562416 correlated with height at ages 3, 8, and 10 years. We could not detect any significant relationship between GHSR SNPs and weight or BMI.

GHSR mutations have been shown to decrease constitutive activity of GHSR, which signals at 50\% of its maximal capacity in vitro, even in the absence of a ligand (8). Based on the functional analyses of deleterious GHSR mutations in short and/or GH-deficient patients showing decreased constitutive GHSR activity $(9,10,11)$, genetic alterations of GHSR would be expected to have an ascertainable growth, even if minor influence on childhood growth. Very recently, Legendre et al. (20) found an up to 5\% occurrence of causative GHSR mutations in a cohort of 290 patients with short stature and/or GH deficiency. As ghrelin promotes GH secretion by increasing hypothalamic GHRH release and by antagonizing the somatostatin block (21), changes in GHSR activity would be expected to change GH secretion, altering GH/IGF-mediated longitudinal growth.

We chose the first decade of postnatal life for analysis. During this time period, rapid infant growth (0-3 years) decelerates to the childhood growth pattern before puberty. As no major influence from sex steroids occurs during this stage, growth largely reflects the role of the GH/IGF system. In fact, the vast majority of subjects were prepubertal at year 10, with menarche having occurred in only $2.6 \%$ of girls. Hence, the consistent significance of rs482204 in our cohort may well be explained by stimulatory effects on GH mediated via GHSR signaling.

However, GH sensitivity in infants is low and starts to rise continuously from early postnatal life, explaining 


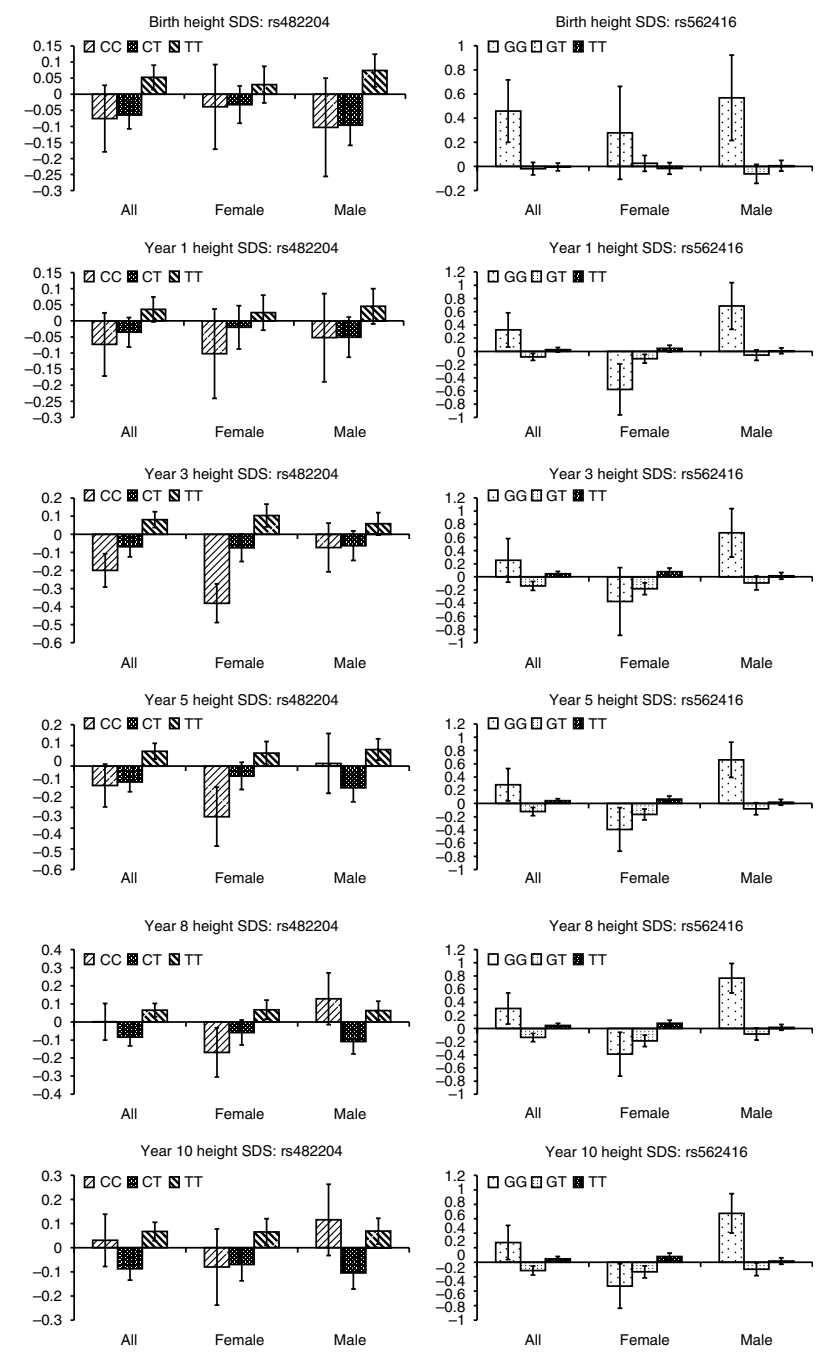

Figure 1 Height SDS (mean \pm S.E.M.) in the whole population for each genotype of the rs482204 (left-hand panels) and rs562416 (right-hand panels) SNPs for each observation year. Graphs show mean heights for the whole population of the observation year in addition to mean heights for females and males specifically. The TT genotype (rs482204) was associated with greater length/height at birth, 3, 5, 8, and 10 years without significant gender differences. The TT genotype (rs562416) correlated positively with height at 3 , 5,8 , and 10 years. Interestingly, the GG genotype (rs562416), though rare $(1.2 \%)$, was associated with significantly greater height in males at $1,5,8$, and 10 years.

the observed minor effect from GH deficiency on growth during early childhood (22). The lack of significance of rs562416 at birth and at 1 year of age as opposed to its influence in later childhood may reflect these developmental changes of GH sensitivity. Correspondingly, no decrease in birth weight was observed in Ghsr null mice (2) or in patients with GHSR missense mutations (9), as far as reported. Therefore, the finding of a positive association between the rs482204 TT genotype with greater birth length was rather unexpected. One might speculate on a non-GH-dependent mechanism: as ghrelin and GHSR mRNAs have been demonstrated in pancreatic islets and ghrelin stimulates insulin secretion (23), GHSR variants may enhance ghrelin-mediated insulin release promoting fetal growth. On the other hand, reduced birth length has also been noted in GH-deficient babies, suggesting a possible minor influence of GH on prenatal growth (24). To our knowledge, rs482204 and rs562416 have not been studied before in relation to stature.

To optimize the screening process to identify allelic differences that were associated with height, we first analyzed the tallest and shortest $27 \%$ (Table 2) before looking at the population as a whole, including possible gender differences (Fig. 1). Comparing these two approaches, results of both, rs482204 and rs562416, were largely consistent with positive correlations between heights and the TT genotype vs $\mathrm{TC} / \mathrm{CC}$ in rs482204 and between heights and the TT genotype vs TG/GG in rs562416. Interestingly, the very small group of GG individuals $(\approx 1.2 \%)$ showed a large variation in heights with significantly taller stature in GG males compared with GG females. Thus, in our population, height in subjects with rs562416 GG genotype appears to be influenced by gender. The small number of GG individuals and the skewing of the gender ratio are in line with possible confounders such as kindredship. For example, the GG individuals in the study population may have come from two extended families with the taller family contributing mostly boys. Therefore, this result should be viewed cautiously.

As opposed to longitudinal height that represents an ideal model for investigation of common inherited traits, weight regulation is influenced by a complex variety of environmental factors in addition to genetic control. Although ghrelin is an orexigenic hormone primarily synthesized by X/A cells of the gastric mucosa, various attempts to relate genetic alterations of either ghrelin $(5,6)$ or the $\operatorname{GHSR}(5,12,13,14,15)$ to body weight have yielded inconsistent results. Baessler et al. (12) found that a disequilibrium block of five GHSR SNPs including rs572169 was associated with obesity. However, this association was not confirmed by other studies $(5,13,14,15)$. Looking at a healthy, nonobese cohort, we also found no association between body weight and GHSR genetic variants.

We chose an LD-based selection of five SNPs across the whole GHSR gene including the promoter and the 3'-UTR region to ensure that potentially important genetic regions were not overlooked. Given that SNPs located within noncoding regions such as promoters, enhancers, and silencers may impact gene regulation (25), it is possible that rs482204 and rs562416, both located within the $3^{\prime}$-UTR outside putative functional domains, may act as regulatory SNPs or affect mRNA stability. Alternatively, they may be in $\mathrm{LD}$ with a functional variant. The observation that each SNP affects height at different, though overlapping, time periods would suggest a regulatory role. Undoubtedly, 
the molecular mechanism(s) underlying our observations will require further research.

As to limitations of our study, we did not have the opportunity to correlate our findings to hormonal parameters (IGF1) within this cohort, although it is plausible that IGF1 levels may in part be accounted for by variation in GHSR activity. Nevertheless, GH-independent factors such as nutritional status also modulate IGF1 levels, which may partly explain why GHSR mutations have not been consistently associated with lower IGF1 levels (9).

Furthermore, to fully characterize GHSR polymorphisms, correlation with parental heights and GHSR genotypes would have been interesting. However, parental DNA samples could not be obtained.

In conclusion, we found consistent associations between GHSR variants and longitudinal height in a population-based cohort of 1362 children followed prospectively from birth to 10 years. Follow-up of this unique cohort to adult height may reveal the functional consequence of these GHSR variants on growth and body weight, while further studies addressing the potential underlying molecular mechanisms of these GHSR variants on growth will be of great interest.

\section{Declaration of interest}

The authors declare that there is no conflict of interest that could be perceived as prejudicing the impartiality of the research reported.

\section{Funding}

This work was supported by a Pfizer Australia Independent Research Grant (S Riedl, C S Choong), Channel Seven Perth Telethon Grant (C S Choong), and APEG Sanofi-Aventis Australia Research Grant (S Riedl, C S Choong).

\section{Acknowledgements}

The authors are indebted to Prof. Michael Waters for critical review of the manuscript. They are particularly thankful to the Raine Study participants and their families, the Raine Study Team for cohort coordination and data collection, the National Health and Medical Research Council (NH \& MRC Australia) for their long-term contribution to funding the study over the last 20 years, and the Telethon Institute for Child Health Research for long-term support of the study. The Raine Study receives core funding from The University of Western Australia, the Telethon Institute for Child Health Research, the Raine Medical Research Foundation, The University of Western Australia Faculty of Medicine, Dentistry, and Health Sciences, the Women and Infant Research Foundation, and Curtin University.

\section{References}

1 Lango Allen H, Estrada K, Lettre G, Berndt SI, Weedon MN, Rivadeneira F, Willer CJ, Jackson AU, Vedantam S, Raychaudhuri S, Ferreira T, Wood AR, Weyant RJ, Segr AV, Speliotes EK, Wheeler E, Soranzo N, Park JH, Yang J, Gudbjartsson D, Heard-Costa NL, Randall JC, Qi L, Vernon Smith A, Mgi R, Pastinen T, Liang L, Heid IM, Luan J, Thorleifsson G, Winkler TW, Goddard ME, SinLo K, Palmer C, Workalemahu T, Aulchenko YS, Johansson A, Zillikens MC,
Feitosa MF, Esko T, Johnson T, Ketkar S, Kraft P, Mangino M, Prokopenko I, Absher D, Albrecht E, Ernst F, Glazer NL, Hayward C, Hottenga JJ, Jacobs KB, Knowles JW, Kutalik Z, Monda KL, Polasek O, Preuss M, Rayner NW, Robertson NR, Steinthorsdottir V, Tyrer JP, Voight BF, Wiklund F, Xu J, Zhao JH, Nyholt DR, Pellikka N, Perola M, Perry JR, Surakka I, Tammesoo ML, Altmaier EL, Amin N, Aspelund T, Bhangale T, Boucher G, Chasman DI, Chen C, Coin L, Cooper MN, Dixon AL, Gibson Q, Grundberg E, Hao K, Juhani Junttila M, Kaplan LM, Kettunen J, Knig IR, Kwan T, Lawrence RW, Levinson DF, Lorentzon M, McKnight B, Morris AP, Mller M, Suh Ngwa J, Purcell S, Rafelt S, Salem RM, Salvi E, Sanna S, Shi J, Sovio U, Thompson JR, Turchin MC, Vandenput L, Verlaan DJ, Vitart V, White CC, Ziegler A, Almgren P, Balmforth AJ, Campbell H, Citterio L, De Grandi A, Dominiczak A, Duan J, Elliott P, Elosua R, Eriksson JG, Freimer NB, Geus EJ, Glorioso N, Haiqing $S$, Hartikainen AL, Havulinna AS, Hicks AA, Hui J, Igl W, Illig T, Jula A, Kajantie E, Kilpelinen TO, Koiranen M, Kolcic I, Koskinen S, Kovacs P, Laitinen J, Liu J, Lokki ML, Marusic A, Maschio A, Meitinger T, Mulas A, Par G, Parker AN, Peden JF, Petersmann A, Pichler I, Pietilinen KH, Pouta A, Ridderstrle M, Rotter JI, Sambrook JG, Sanders AR, Schmidt CO, Sinisalo J, Smit JH, Stringham HM, Bragi Walters G, Widen E, Wild SH, Willemsen G, Zagato L, Zgaga L, Zitting P, Alavere H, Farrall M, McArdle WL, Nelis M, Peters MJ, Ripatti S, van Meurs JB, Aben KK, Ardlie KG, Beckmann JS, Beilby JP, Bergman RN, Bergmann S, Collins FS, Cusi D, den Heijer M, Eiriksdottir G, Gejman PV, Hall AS, Hamsten A, Huikuri HV, Iribarren C, Khnen M, Kaprio J, Kathiresan S, Kiemeney L, Kocher T, Launer LJ, Lehtimki T, Melander O, Mosley TH Jr, Musk AW, Nieminen MS, O'Donnell CJ, Ohlsson C, Oostra B, Palmer LJ, Raitakari O, Ridker PM, Rioux JD, Rissanen A, Rivolta C, Schunkert H, Shuldiner AR, Siscovick DS, Stumvoll M, Tnjes A, Tuomilehto J, van Ommen GJ, Viikari J, Heath AC, Martin NG, Montgomery GW, Province MA, Kayser M, Arnold AM, Atwood LD, Boerwinkle E, Chanock SJ, Deloukas P, Gieger C, Grnberg H, Hall P, Hattersley AT, Hengstenberg C, Hoffman W, Lathrop GM, Salomaa V, Schreiber S, Uda M, Waterworth D, Wright AF, Assimes TL, Barroso I, Hofman A, Mohlke KL, Boomsma DI, Caulfield MJ, Cupples LA, Erdmann J, Fox CS, Gudnason V, Gyllensten U, Harris TB, Hayes RB, Jarvelin MR, Mooser V, Munroe PB, Ouwehand WH, Penninx BW, Pramstaller PP, Quertermous T, Rudan I, Samani NJ, Spector TD, Vlzke H, Watkins H, Wilson JF, Groop LC, Haritunians T, Hu FB, Kaplan RC, Metspalu A, North KE, Schlessinger D, Wareham NJ, Hunter DJ, O'Connell JR, Strachan DP, Wichmann HE, Borecki IB, van Duijn CM, Schadt EE, Thorsteinsdottir U, Peltonen L, Uitterlinden AG, Visscher PM, Chatterjee N, Loos RJ, Boehnke M, McCarthy MI, Ingelsson E, Lindgren CM, Abecasis GR, Stefansson K, Frayling TM \& Hirschhorn JN. Hundreds of variants clustered in genomic loci and biological pathways affect human height. Nature $2010 \mathbf{4 6 7}$ 832-838. (doi:10.1038/nature09410)

2 Sun Y, Wang P, Zheng H \& Smith RG. Ghrelin stimulation of growth hormone release and appetite is mediated through the growth hormone secretagogue receptor. PNAS 2004101 4679-4684. (doi:10.1073/pnas.0305930101)

3 Korbonits M, Goldstone AP, Gueorguiev M \& Grossman AB. Ghrelin - a hormone with multiple functions. Frontiers in Neuroendocrinology 200425 27-68. (doi:10.1016/j.yfrne.2004. 03.002)

4 Gueorguiev M, Lecoeur C, Benzinou M, Mein CA, Meyre D, Vatin V, Weill J, Heude B, Grossman AB, Froguel P \& Korbonits M. A genetic study of the ghrelin and growth hormone secretagogue receptor (GHSR) genes and stature. Annals of Human Genetics 2009 73 1-9. (doi:10.1111/j.1469-1809.2008.00484.x)

5 Gueorguiev M, Lecoeur C, Meyre D, Benzinou M, Mein CA, Hinney A, Vatin V, Weill J, Heude B, Hebebrand J, Grossman AB, Korbonits M \& Froguel P. Association studies on ghrelin and ghrelin receptor gene polymorphisms with obesity. Obesity 2009 17 745-754. (doi:10.1038/oby.2008.589) 
6 Vivenza D, Rapa A, Castellino N, Bellone S, Petri A, Vacca G, Aimaretti G, Broglio F \& Bona G. Ghrelin gene polymorphisms and ghrelin, insulin, IGF-I, leptin and anthropometric data in children and adolescents. European Journal of Endocrinology 2004 151 127-133. (doi:10.1530/eje.0.1510127)

7 Howard AD, Feighner SD, Cully DF, Arena JP, Liberator PA, Rosenblum CI, Hamelin M, Hreniuk DL, Palyha OC, Anderson J, Paress PS, Diaz C, Chou M, Liu KK, McKee KK, Pong SS, Chaung LY, Elbrecht A, Dashkevicz M, Heavens R, Rigby M, Sirinathsinghji DJ, Dean DC, Melillo DG, Patchett AA, Nargund R, Griffin PR, DeMartino JA, Gupta SK, Schaeffer JM, Smith RG \& Van der Ploeg LH. A receptor in pituitary and hypothalamus that functions in growth hormone release. Science $1996 \mathbf{2 7 3} 974-977$. (doi:10.1126/science.273.5277.974)

8 Holst B, Cygankiewicz A, Jensen TH, Ankersen M \& Schwartz TW. High constitutive signaling of the ghrelin receptor-identification of a potent inverse agonist. Molecular Endocrinology 200317 2201-2210. (doi:10.1210/me.2003-0069)

9 Pantel J, Legendre M, Cabrol S, Hilal L, Hajaji Y, Morisset S, Nivot S, Vie-Luton MP, Grouselle D, de Kerdanet M, Kadiri A, Epelbaum J, Le Bouc Y \& Amselem S. Loss of constitutive activity of the growth hormone secretagogue receptor in familial short stature. Journal of Clinical Investigation $2006 \quad 116$ 760-768. (doi:10.1172/ JCI25303)

10 Pantel J, Legendre M, Nivot S, Morisset S, Vie-Luton MP, Le Bouc Y, Epelbaum J \& Amselem S. Recessive isolated growth hormone deficiency and mutations in the ghrelin receptor. Journal of Clinical Endocrinology and Metabolism 200994 4334-4341. (doi:10. 1210/jc.2009-1327)

11 Inoue H, Kangawa N, Kinouchi A, Sakamoto Y, Kimura C, Horikawa R, Shigematsu Y, Itakura M, Ogata T, Fujieda K \& Japan Growth Genome Consortium. Identification and functional analysis of novel human growth hormone secretagogue receptor (GHSR) gene mutations in Japanese subjects with short stature. Journal of Clinical Endocrinology and Metabolism 201196 E373-E378. (doi:10.1210/jc.2010-1570)

12 Baessler A, Hasinoff MJ, Fischer M, Reinhard W, Sonnenberg GE, Olivier M, Erdmann J, Schunkert H, Doering A, Jacob HJ, Comuzzie AG, Kissebah AH \& Kwitek AE. Genetic linkage and association of the growth hormone secretagogue receptor (ghrelin receptor) gene in human obesity. Diabetes $2005 \mathbf{5 4} 259-267$. (doi:10.2337/diabetes.54.1.259)

13 Wang HJ, Geller F, Dempfle A, Schäuble N, Friedel S, Lichtner P, Fontenla-Horro F, Wudy S, Hagemann S, Gortner L, Huse K, Remschmidt H, Bettecken T, Meitinger T, Schäfer H, Hebebrand J \& Hinney A. Ghrelin receptor gene: identification of several sequence variants in extremely obese children and adolescents, healthy normal-weight and underweight students, and children with short normal stature. Journal of Clinical Endocrinology and Metabolism 200489 157-162. (doi:10.1210/jc.2003-031395)

14 Garcia EA, Heude B, Petry CJ, Gueorguiev M, Hassan-Smith ZK, Spanou A, Ring SM, Dunger DB, Wareham N, Sandhu MS, Ong KK \& Korbonits M. Ghrelin receptor gene polymorphisms and body size in children and adults. Journal of Clinical Endocrinology and Metabolism 200893 4158-4161. (doi:10.1210/jc.2008-0366)

15 Gjesing AP, Larsen LH, Torekov SS, Hainerová IA, Kapur R, Johansen A, Albrechtsen A, Boj S, Holst B, Harper A, Urhammer SA, Borch-Johnsen K, Pisinger C, Echwald SM, Eiberg H, Astrup A, Lebl J, Ferrer J, Schwartz TW, Hansen T \&
Pedersen O. Family and population-based studies of variation within the ghrelin receptor locus in relation to measures of obesity. PLoS ONE 20105 e10084. (doi:10.1371/journal.pone.0010084)

16 Newnham JP, Evans SF, Michael CA, Stanley FJ \& Landau LI. Effects of frequent 469 ultrasound during pregnancy: a randomised controlled trial. Lancet 1993342 887-891. (doi:10.1016/ 0140-6736(93)91944-H)

17 Ye S, Dhillon S, Ke X, Collins AR \& Day IN. An efficient procedure for genotyping single nucleotide polymorphisms. Nucleic Acids Research 200129 E88. (doi:10.1093/nar/29.17.e88)

18 Ollivier L, Messer LA, Rothschild MF \& Legault C. The use of selection experiments for detecting quantitative trait loci. Genetical Research 199769 227-232. (doi:10.1017/S001667 2397002802)

19 Jawaid A, Bader JS, Purcell S, Cherny SS \& Sham P. Optimal selection strategies for QTL mapping using pooled DNA samples. European Journal of Human Genetics 200210 125-132. (doi:10.1038/sj.ejhg.5200771)

20 Legendre M, Pantel J, Lazea C, Cabrol S, Collot N, Dastot F, Duquesnoy P, Hilal L, Kadiri A, Dupuis C, Nivot S, Rose S, Rothenbuhler A, Sobrier ML, Vie-Luton MP, LeBouc Y, Polak M, Léger J \& Amselem S. Contribution of ghrelin receptor (GHSR) mutations to short stature in humans - identification of new variants. Hormone Research 201176 (Suppl 2) 29-30 (Abstract (FC5-109), held at the 50th Annual Meeting of the European Society for Pediatric Endocrinology, Glasgow, UK, Sept 2011).

21 Wagner C, Caplan SR \& Tannenbaum GS. Interactions of ghrelin signaling pathways with the $\mathrm{GH}$ neuroendocrine axis: a new and experimentally tested model. Journal of Molecular Endocrinology 200943 105-119. (doi:10.1677/JME-09-0023)

22 Ranke MB, Lindberg A, Albertsson-Wikland K, Wilton P, Price DA \& Reiter EO. Increased response, but lower responsiveness, to growth hormone $(\mathrm{GH})$ in very young children (aged 0-3 years) with idiopathic GH Deficiency: analysis of data from KIGS. Journal of Clinical Endocrinology and Metabolism $2005901966-$ 1971. (doi:10.1210/jc.2004-1051)

23 Date Y, Nakazato M, Hashiguchi S, Dezaki K, Mondal MS, Hosoda H, Kojima M, Kangawa K, Arima T, Matsuo H, Yada T \& Matsukura S. Ghrelin is present in pancreatic alpha-cells of humans and rats and stimulates insulin secretion. Diabetes 2002 51 124-129. (doi:10.2337/diabetes.51.1.124)

24 Gluckman PD, Gunn AJ, Wray A, Cutfield WS, Chatelain PG, Guilbaud O, Ambler GR, Wilton P \& Albertsson-Wikland K. Congenital idiopathic growth hormone deficiency associated with prenatal and early postnatal growth failure. The International Board of the Kabi Pharmacia International Growth Study. Journal of Pediatrics 1992121 920-923. (doi:10.1016/S00223476(05)80342-7)

25 Chorley BN, Wang X, Campbell MR, Pittman GS, Noureddine MA \& Bell DA. Discovery and verification of functional single nucleotide polymorphisms in regulatory genomic regions: current and developing technologies. Mutation Research 2008 659 147-157. (doi:10.1016/j.mrrev.2008.05.001)

Received 28 December 2011

Revised version received 26 February 2012

Accepted 28 March 2012 